\title{
Quality of pejerrey (Odontesthes bonariensis) eggs and larvae in captivity throughout spawning season
}

\author{
Tomás Chalde, Mariano Elisio and Leandro A. Miranda
}

The aim of this work was to assess the quality of pejerrey eggs and larvae throughout its spawning season. Fertilized eggs were taken on September, October, November, and December from a captive broodstock. The egg diameter, yolk diameter, and oil droplets area decreased along the spawning season, with higher values in September. Fertilization and hatching rates decreased throughout this period, with highest values in September $(88.0 \% ; 55.2 \%)$ and the lowest values on December $(43.0 \% ; 25.2 \%)$. The larvae hatched from eggs obtained on October were the heaviest and longest $(1.57 \mathrm{mg} ; 8.24 \mathrm{~mm})$. The survival rate at 30 days post hatching (dph) was similar in larvae from September and October eggs $(66.1 \% ; 62.9 \%)$ with a sharp decrease in larvae from November and December eggs (22.4\%; 23.3\%). Furthermore, the highest body weight (15.1 mg) and total length $(15.25 \mathrm{~mm})$ at $30 \mathrm{dph}$ were obtained in larvae from October eggs. The results obtained showed that overall eggs quality was better at the beginning of the spawning period, influencing the larvae performance.

O objetivo deste trabalho foi avaliar a qualidade de ovos de peixe-rei ao longo do período reprodutivo. Ovos fertilizados foram amostrados em setembro, outubro, novembro e dezembro de reprodutores em cativeiro. O diâmetro do ovo e do vitelo, como também o tamanho das gotículas de óleo diminuíram ao longo do período reprodutivo, com valores maiores em setembro. Taxas de fertilização e eclosão diminuíram ao longo deste período, apresentando valores maiores em setembro $(88,0 \%, 55,2 \%)$ e menores em dezembro $(43,0 \%, 25,2 \%)$. As larvas eclodidas dos ovos, obtidas em outubro, eram maiores e apresentavam maior peso $(8,24 \mathrm{~mm} ; 1,57 \mathrm{mg})$. A taxa de sobrevivência aos 30 dias pós-eclosão foi maior nos meses de setembro e outubro, apresentando valores similares $(66,1 \%, 62,9 \%)$, no entanto, houve uma diminuição acentuada na sobrevivência das larvas de ovos em novembro e dezembro $(22,4 \%, 23,3 \%)$. Além disso, o maior peso corporal $(15,1 \mathrm{mg})$ e o comprimento total $(15,25 \mathrm{~mm})$ aos 30 dias pós-eclosão foram obtidos a partir de larvas de ovos durante o mês de outubro. Os resultados obtidos mostraram que a qualidade dos ovos em geral foi melhor no início do período reprodutivo, influenciando o desempenho das larvas.

Key words: Aquaculture, Eggs and larvae quality, Pejerrey, Reproductive season.

\section{Introduction}

Pejerrey Odontesthes bonariensis (Valenciennes, 1835) is considered the most important native fish of the Pampas region of Argentina due to the high value of its flesh and its attractiveness for anglers (Somoza et al., 2008). The constant overfish exerted on pejerrey wild populations, the increasing pollution of its habitat and the importance of native species farming to avoid the negative impact of exotic species (Ross et al., 2008), have made necessary the development of its aquaculture. Pejerrey culture techniques have been successfully developed in several aspects (Somoza et al., 2008) including natural spawning in tanks, increase in milt production, spawning synchronization by hormonal treatments, and development of sperm cryopreservation techniques (Miranda et al., 2005; Miranda et al., 2006; Somoza et al., 2006; Miranda \& Somoza 2009; Lichtenstein et al., 2010). On the other hand, the high mortality and deformities observed during larvae and juveniles development in combination with the slow growth rates compared to others aquaculture fish species (Luchini et al., 1984) are the disadvantages of pejerrey cultivation at a commercial scale (Somoza et al., 2008).

Odontesthes bonariensis is an iteroparous and multiple spawner fish with a major spawning period during spring (with a peak in October) and a smaller one in autumn (Calvo \& Morriconi, 1972; Strüssmann, 1989). In captivity it is possible

Laboratorio de Ictiofisiología y Acuicultura. Instituto de Investigaciones Biotecnológicas-Instituto Tecnológico de Chascomús (CONICET -UNSAM). Av. Intendente Marino Km. 8,200. (B7130IWA) Chascomús, Buenos Aires, Argentina. lmiranda@intech.gov.ar (corresponding author), tomaschalde@intech.gov.ar,melisio@intech.gov.ar 
to carry out a full life cycle of pejerrey in tanks (Miranda et al., 2006), obtaining eggs by natural spawning practically throughout all the year, with a period of high reproductive activity from September to December (Miranda \& Somoza, 2009). However, large differences in larvae performance were observed along this period (Miranda et al., 2006; Somoza et al., 2008). Also, it has been found differences in eggs size among groups of pejerrey treated with different temperature and photoperiod regimes (Strüssmann, 1989).

In this sense, it is known that the quality of gametes, defined as its ability to fertilize or to be fertilized and subsequently develop into a normal embryo (Bobe \& Labbé, 2010), decreases throughout the reproductive cycle in multiple spawner fish (Ojanguren et al., 1996; Alavi et al., 2008; Rouxel et al., 2008; Policar et al., 2010). The quality of eggs can be affected by several factors such as age and condition factor of the broodstock, the timing of the spawning, genetic, and also by intrinsic properties of the eggs (Kjørsvik et al., 1990; Brooks et al., 1997). In some fish species, it has been observed that bigger eggs produce bigger newly hatched larvae providing advantage for growth and survival of fingerlings (Brooks et al., 1997).

Because the large differences observed in pejerrey gametes quality throughout spawning period, the aim of this work was to quantify its quality in terms of: fertilization and hatching rates, eggs and yolk size, and larvae growth and survival rate, in order to determine the best time for obtaining embryos and improve the management of larvae production.

\section{Material and Methods}

\section{Eggs Collection}

Eggs were obtained from a 5+ aged broodstock of 300 fish ( 2 males: 1 female; body weight: $600.4 \pm 150.4 \mathrm{~g}$; total length $39.8 \pm 3.4 \mathrm{~cm}$; mean $\pm \mathrm{SD} ; \mathrm{n}=25$; Condition index $(\mathrm{K})$ : 0.95) from the Estación Hidrobológica de Chascomús facilities (Chascomús, Buenos Aires, Argentina). This broodstock was chosen because it has been monitored since puberty and from which were obtained large amounts of eggs in previous reproductive seasons. Fish were kept in $80,000 \mathrm{~L}$ outdoor circular tank with flow-through water (1.1 exchanges / day; $15 \mathrm{~g} / \mathrm{L}$ salinity). Spawned eggs (40,000 to $70,000)$ were collected on the $10^{\text {th }}$ of September, October, November, and December of 2009 and carried to the Instituto de Investigaciones Biotecnológicas - Instituto Tecnológico de Chascomús (Chascomús, Buenos Aires, Argentina). Water temperature was recorded every day during the experimental time in the broodstock tank while the oxygen concentration was measured once a week with an oxygen meter Hanna HI 9143 (Hanna Instruments Srl, Italy). Fish were handfed to satiation twice a day with a commercial pellet of 3 mm (protein: 42.9\%; lipids: 1.5\%; carbohydrates: 43.8\%; phosphorus: 2.9\%; Shullet, Argentina).

\section{Eggs and larvae measurements}

Approximately a group of 200 eggs was taken from each sample and photographed under a stereomicroscope and analyzed using Image-pro plus 4.0 Software in order to

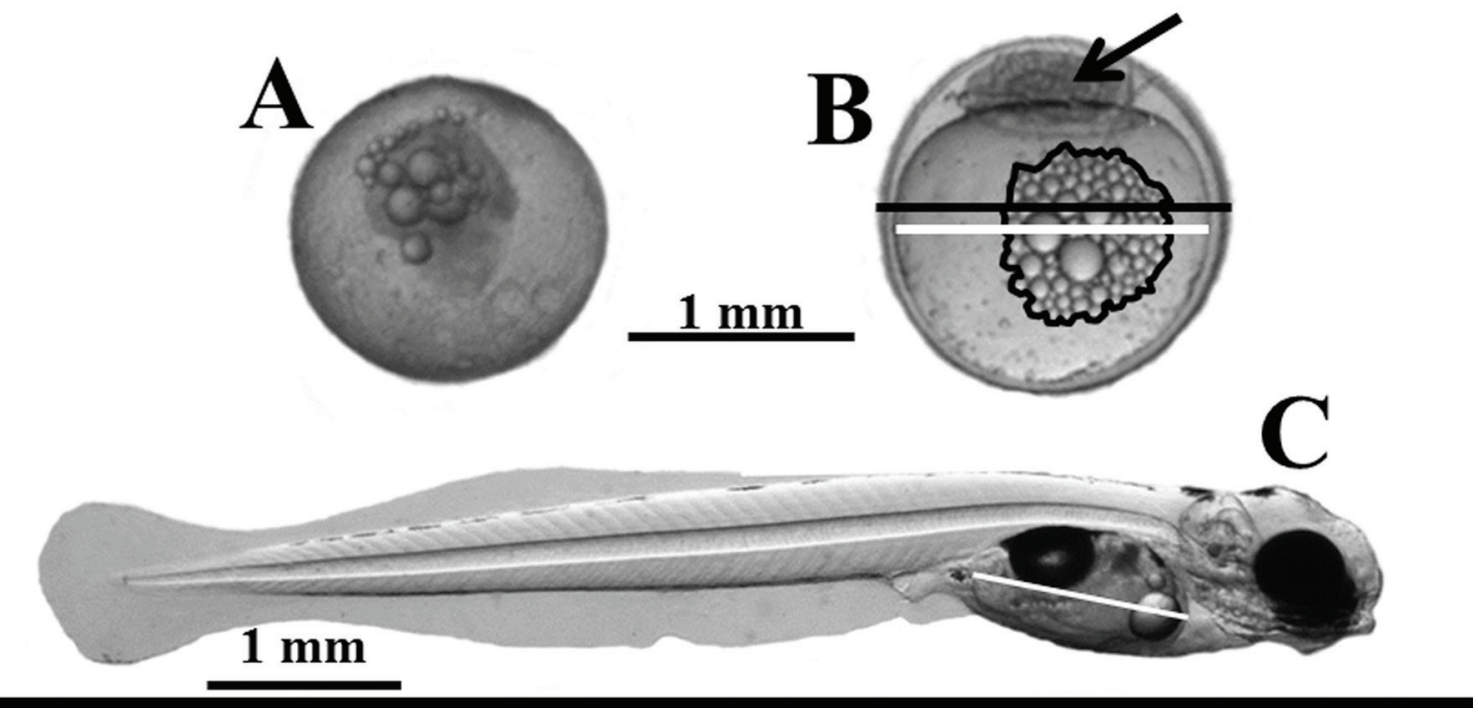

Fig. 1. A. General aspect of unfertilized egg and B. morphometric measurement procedures for pejerrey eggs in blastula stage (arrow). White and black lines indicate the egg diameter and the yolk diameter, respectively. Oil droplets area is surrounded by a black line. C. newly hatched larva; the white line indicates the length of the yolk sac. 

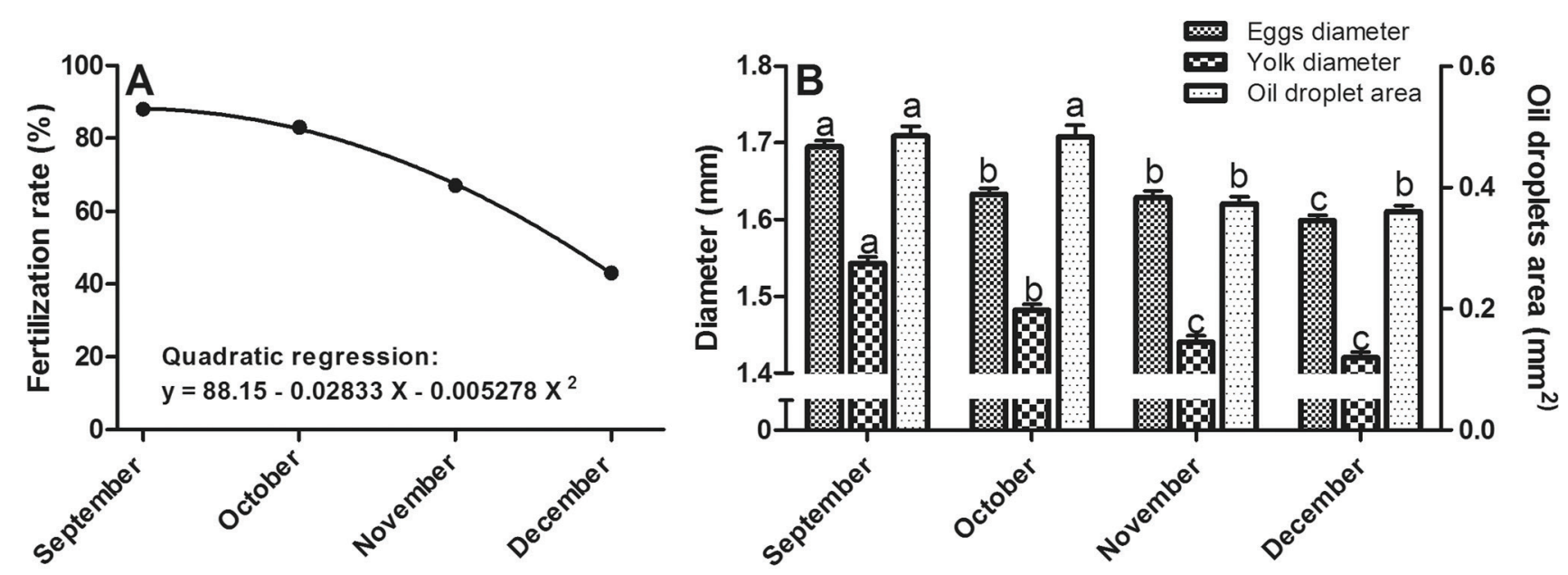

Fig. 2. Pejerrey egg measurements throughout the reproductive season. (A) Changes of pejerrey fertilization rate, quadratic regression with abscissas in days between 0 (September $10^{\text {th }}$ ) and 90 (December $\left.10^{\text {th }}\right) ; \mathrm{R}^{2}=0.9623$. (B) Changes of pejerrey egg measurements across the reproductive period analyzed. Different letters indicate mean statistical differences. ANOVA followed by Bonferroni's multiple comparison tests $(\mathrm{n}=50 ; P \leq 0.05)$.

estimate the fertilization rate. Eggs perfectly rounded and transparent with an embryo in blastula stage were considered as fertilized (Fig. 1A-B). Egg and yolk diameter (measured perpendicular to the animal pole), and oil droplets area were measured in 50 fertilized eggs (Fig. 1B). On each sample, two groups of 2,000 fertilized eggs were hand separated and incubated at $18.0 \pm 0.6{ }^{\circ} \mathrm{C}$ (mean $\pm \mathrm{SD}$ ) in a flow-through water (4 g / L salinity) incubating jar. At hatch, larvae were counted in order to estimate the hatching rate and 15 larvae were randomly sampled from each batch and photographed under a stereomicroscope to measure the total body length and the yolk sac length (Fig. 1C) to the nearest decimal millimeter using Image-pro plus 4.0 Software. Besides, body weight was measured at the nearest decimal milligram with an analytical balance. Finally, two replicates of 1,000 newly hatched larvae from each month were reared at optimal condition for this species (Chalde et al., unpublished): 8.3 larva / L, flowthrough water with 1 exchange $(120 \mathrm{~L}) / 4.5 \mathrm{~h} ; 15 \mathrm{~g} / \mathrm{L}$ of salinity and with a photoperiod of $12 \mathrm{~h}$ light: $12 \mathrm{~h}$ dark. Water temperature $\left(23.3 \pm 0.9^{\circ} \mathrm{C}\right.$; mean $\left.\pm \mathrm{SD}\right)$ and dissolved oxygen $(6.43 \pm 0.14 \mathrm{mg} / \mathrm{L}$; mean $\pm \mathrm{SD})$ were recorded every day. Fish were fed with $2 \mathrm{~g}$ of Artemia nauplii (Aquatic Enterprise Co., Sarawak, Malaysia), four times a day. After 30 days post hatching (dph) body weight (nearest decimal milligram) with an analytical balance and total length (nearest decimal millimeter) with a digital caliper were measured. Total larvae number was counted to estimate the survival rate.

\section{Statistical analysis}

Second order polynomial regression was used to describe the relationship between fertilization rates and sampling dates, while linear regression were used to examine relationships between hatching rates with sampling dates and with fertilization rates. Eggs, newly hatched larvae and $30 \mathrm{dph}$ larvae measurements were analyzed by one-way ANOVA followed by Bonferroni's multiple comparison tests $(\mathrm{P} \leq 0.05)$. Data are presented as the mean \pm SEM. Statistical analyses were performed using GraphPad Prism 5.0 Software.

\section{Results}

Oxygen concentration (6.6-8.65 mg / L; min-max) and water temperature $\left(16-24{ }^{\circ} \mathrm{C}\right.$; min-max $)$ recorded in broodstock tank during the experimental time were within the optimum for pejerrey cultivation (Gómez et al., 2007). Fertilization rate showed a nonlinear relation throughout the reproductive season $\left(\mathrm{R}^{2}=0.9623\right.$, Fig. $\left.2 \mathrm{~A}\right)$, with the highest value in September (88\%) and the lowest in December (43\%).

The eggs of September were significantly bigger (1.695 $\pm 0.008 \mathrm{~mm}$ ) than eggs of other months, but there was no difference between eggs of October and November, meanwhile December eggs were significantly smaller $(1.599 \pm 0.006 \mathrm{~mm})$ than the rest (Fig. 2B). Also, significant differences were found in yolk diameter, with maximum value on September (1.543 \pm $0.008 \mathrm{~mm})$ with a decrease in October $(1.482 \pm 0.007 \mathrm{~mm})$ and minimum values on November and December $(1.440 \pm 0.008$ and $1.420 \pm 0.007 \mathrm{~mm}$, Fig. 2B). Oil droplets area (Fig. 2B) was significantly higher on September and October (0.485 \pm $0.016 \mathrm{~mm}^{2}$ and $\left.0.483 \pm 0.019 \mathrm{~mm}^{2}\right)$ and lower on November and December $\left(0.373 \pm 0.011 \mathrm{~mm}^{2}\right.$ and $\left.0.360 \pm 0.010 \mathrm{~mm}^{2}\right)$. Furthermore, hatching rate was higher at the beginning of the reproductive season and decreased significantly from September to December, ranging from $55.2 \%$ to $25.2 \%$ (Fig. $3 \mathrm{~A})$. Also, a high relationship $\left(\mathrm{R}^{2}=0.9478 ; P \leq 0.05\right)$ between hatching rate and fertilization rate was observed (Fig. 3B). 

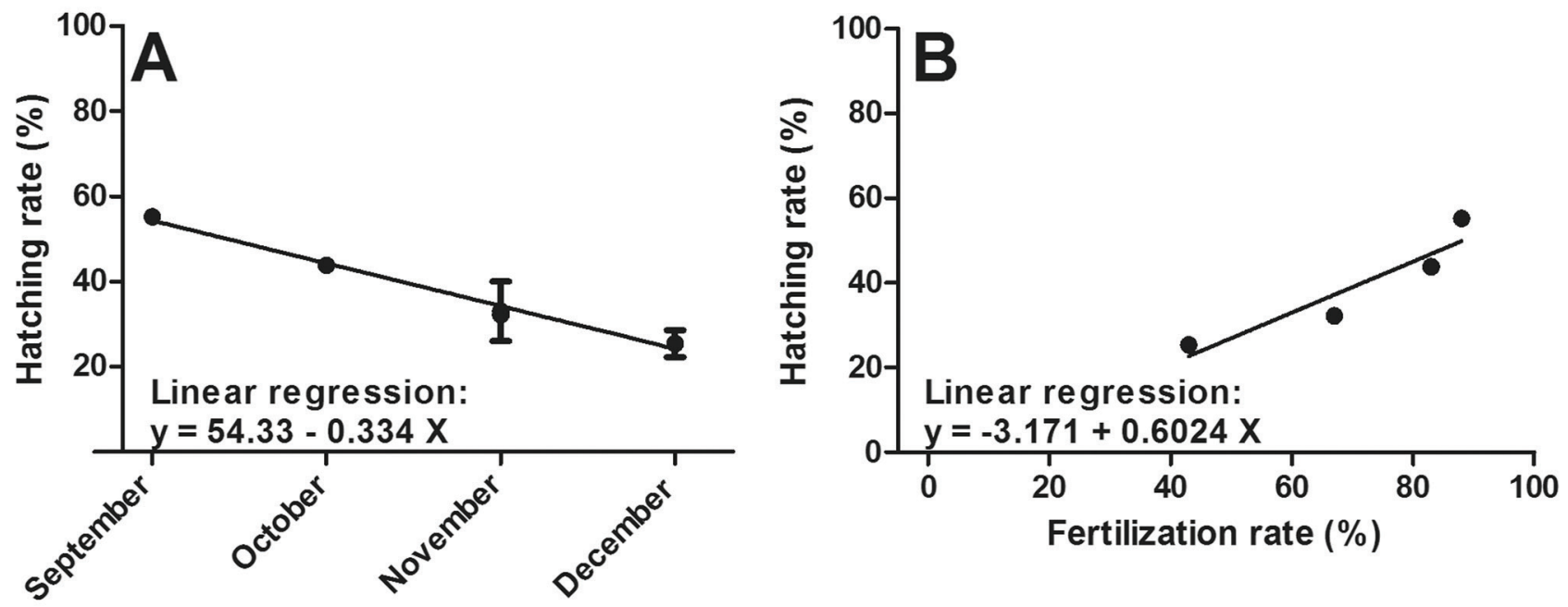

Fig. 3. (A) Linear regression between pejerrey hatching rate and sampling dates during reproductive season; $\mathrm{R}^{2}=-0.9948 ; P$ $\leq 0.05$. (B) linear regression between fertilization rate and hatching rate (square root transformed data); $\mathrm{R}^{2}=0.9478 ; P \leq 0.05$.

For all groups, embryos incubation time was 14 days. The newly hatched larvae from September and October eggs were not different and significantly heavier than those hatched from November and December eggs that also did not show differences between them (Table 1). However, only larvae from October eggs were significantly longer compared with the other group (Table 1). No difference in the yolk sac length was found between groups (Table 1). After $30 \mathrm{dph}$ heavier larvae were obtained from eggs of September and October, but only the larvae from October were significantly different than November and December larvae. In the case of total length, longer larvae were obtained from eggs of October and November, however only larvae from October were significantly difference than September and December fish (Table 1). The larvae from September and October eggs showed similar survival rate being significantly higher than those from eggs of November and December (Table 1).

\section{Discussion}

In this study, it was demonstrated that pejerrey fertilization rate and eggs size decreased throughout the reproductive season. In this sense, it should be considered a possible decline in sperm quality during spawning affecting fertilization as it has been seen in other species (Babiak et al., 2006; Alavi et al., 2008; Rouxel et al., 2008; Cabrita et al., 2011).

As it was mentioned, heavier hatched larvae were obtained at the beginning of spawning season (September and October) and these larvae showed the highest growth in weight and survival rate after $30 \mathrm{dph}$. Taking into account these results it is possible to assume that the size at hatching may be related to the performance of the larvae, particularly with the skills to get live feed. Similar findings were reported in other fish, such as Iceland cod (Gadus morhua), Siberian sturgeon (Acipenser baeri), Eurasian perch (Perca fluviatilis)

Table 1. Pejerrey larvae measurements at hatching and after 30 dph (mean + SEM). Different letters indicate statistical differences. ANOVA followed by Bonferroni's multiple comparison tests $(n=30$; except for survival rate $n=2 ; P \leq 0.05)$.

\begin{tabular}{|c|c|c|c|c|c|}
\hline & & September & October & November & December \\
\hline \multicolumn{6}{|l|}{ Hatching } \\
\hline & Body weight (mg) & $1.56 \pm 0.04 \mathrm{a}$ & $1.57 \pm 0.06 \mathrm{a}$ & $1.28 \pm 0.03 b$ & $1.37 \pm 0.05 b$ \\
\hline & Total length (mm) & $7.69 \pm 0.06 a$ & $8.24 \pm 0.09 b$ & $7.69 \pm 0.06 \mathrm{a}$ & $7.62 \pm 0.07 \mathrm{a}$ \\
\hline & Yolk-sac length (mm) & $1.20 \pm 0.03 \mathrm{a}$ & $1.22 \pm 0.03 \mathrm{a}$ & $1.20 \pm 0.03 \mathrm{a}$ & $1.18 \pm 0.02 \mathrm{a}$ \\
\hline \multicolumn{6}{|l|}{$30 \mathrm{dph}$} \\
\hline & Body weight (mg) & $12.4 \pm 1.2 \mathrm{ab}$ & $15.1 \pm 1.1 \mathrm{~b}$ & $9.77 \pm 1.06 \mathrm{a}$ & $8.50 \pm 1.17 \mathrm{a}$ \\
\hline & Total length (mm) & $13.9 \pm 0.4 \mathrm{a}$ & $15.3 \pm 0.2 b$ & $14.1 \pm 0.4 \mathrm{ab}$ & $12.6 \pm 0.4 \mathrm{a}$ \\
\hline & Survival rate (\%) & $66.1 \pm 0.1 \mathrm{a}$ & $62.9 \pm 1.7 \mathrm{a}$ & $22.4 \pm 9.4 b$ & $23.3 \pm 0.7 b$ \\
\hline
\end{tabular}


and Walleye (Sander vitreus) (Marteinsdottir \& Steinarsson, 1998; Johnston et al., 2007; Gisbert et al., 2000; Johnston et al., 2007; Huss et al., 2007). Moreover, it should be noted that in this study the growth of larvae obtained from eggs of September and October may have been underestimated due to higher survival compared with the other months, resulting in a greater rearing density.

The oil droplets area found in pejerrey eggs was higher at the beginning of the reproductive season. These kind of multiple oil droplets are presented in the eggs of all Atheriniformes (Rosen \& Parenti, 1981), as pejerrey, in which coalesce completely in a single large droplet during the embryogenesis, remaining in post hatched larvae (Chalde et al., 2011). The function of these oil droplets during fish development is not clearly understood, but it has been proposed that these are the main metabolic fuel after hatching (Wiegand, 1996). In this sense, the high growth in weight and survival of the larvae obtained from eggs of September and October could be caused by the higher amount of oil.

Bigger oocytes, as that observed at the beginning of the reproductive season, may imply more yolk resulting in larvae with larger amount of reserves. In this sense, it has been reported that pejerrey larvae with largest reserves began exogenous feeding later, promoting the larvae survival (Strüssmann \& Takashima, 1989). Nevertheless in this study it was not observed statistically differences in yolk sac length between groups despite the difference in the size of eggs. This lack of difference might be because it was not possible to estimate the volume of the yolk sac assuming an ellipsoidal shape which is a better estimator of yolk amount (Gisbert $e t$ al., 2000; Jardine \& Litvak, 2003; Uusi-Heikkilä et al., 2010). The difficulty of estimating the yolk sac volume in pejerrey is due to the presence of melanophores and a prominent swim bladder in the newly hatched larva (Chalde et al., 2011), that hinder the dorsal limit of the yolk sac.

It is possible to assume that the increase of water temperature throughout the reproductive season (from 16 to $24^{\circ} \mathrm{C}$ ) has provoked a decrease in estradiol and vitellogenin levels, resulting in smaller eggs with low amount of energy reserves. In this sense, it is known that vitellogenin plasma levels, the precursor of egg yolk, decreased in fish kept at high water temperatures impairing its reproductive activity (King et al., 2007; Pankhurst \& King, 2010; Miranda et al., 2013).

In conclusion, the decrease of pejerrey eggs quality throughout the spawning season reported in this study lead us to focus on the effort to produce eggs and larvae for aquaculture during September and October. This becomes essential if the objective is wild stock repopulation. In this sense it is important to mention that as part of a long time tradition in Argentina, larvae and juveniles of pejerrey are being released every year in shallow lakes and rivers of different Argentine provinces (Velasco et al., 2008). Following the results of this work, we suggested to drive the repopulation with larvae obtained at the beginning of the reproductive season. However, if larvae production strategy is focused on having eggs of good quality during a longer period, it should be necessary to study other parameters such as broodstock age, quality and quantity of broodstock feed, water temperature and photoperiod.

\section{Acknowledgments}

The authors would like to thank Gustavo Berasain from Estación Hidrobiológica de Chascomús. This work was supported by ANPCyT, PICT 2012 (1530) and CONICET, PIP Res. D. N ${ }^{\circ} 1673 / 12$ to LAM.

\section{Literature Cited}

Alavi, S. M. H., M. Psenicka, M. Rodina, T. Policar \& O. Linhart. 2008. Changes of sperm morphology, volume, density and motility and seminal plasma composition in Barbus barbus (Teleostei: Cyprinidae) during the reproductive season. Aquatic Living Resources, 21: 75-80.

Babiak, I., O. Ottesen, G. Rudolfsen \& S. Johnsen. 2006. Quantitative characteristics of Atlantic halibut, Hippoglossus hippoglossus L., semen throughout the reproductive season. Theriogenology, 65: 1587-1604.

Bobe, J. \& C. Labbé. 2010. Egg and sperm quality in fish. General and Comparative Endocrinology, 165: 535-548.

Brooks, S., C. R. Tyler \& J. P. Sumpter. 1997. Egg quality in fish: what makes a good egg? Reviews in Fish Biology and Fisheries, 7: 387-416.

Cabrita, E., F. Soares, J. Beirão, A. García-López, G. MartínezRodríguez \& M. T. Dinis. 2011. Endocrine and milt response of Senegalese sole, Solea senegalensis, males maintained in captivity. Theriogenology, 75: 1-9.

Calvo, J. \& E. R. Morriconi. 1972. Fenómenos reproductivos en el pejerrey (Odontesthes bonariensis) III. Estudio de la fecundidad, época y número de desoves. Anales de la Sociedad Científica Argentina Argentina, 93: 75-84.

Chalde, T., D. A. Fernández, V. E. Cussac \& G. M. Somoza. 2011. The effect of rearing temperature in larval development of pejerrey, Odontesthes bonariensis - Morphological indicators of development. Neotropical Ichthyology, 9: 747-756.

Gisbert, E., P. Williot \& F. Castelló-Orvay. 2000. Influence of egg size on growth and survival of early stages of Siberian sturgeon (Acipenser baeri) under small scale hatchery conditions. Aquaculture, 183: 83-94.

Gómez, S. E., R. C. Menni, J. Gonzalez Naya \& L. Ramirez. 2007. The physical - chemical habitat of the Buenos Aires pejerrey, Odontesthes bonariensis (Teleostei, Atherinopsidae), with a proposal of a water quality index. Environmental Biology of Fishes, 78: 161-171.

Huss, M., L. Persson \& P. Byström. 2007. The origin and development of individual size variation in early pelagic stages of fish. Oecologia, 153: 57-67.

Jardine, D. \& M. K. Litvak. 2003. Direct yolk sac volume manipulation of zebrafish embryos and the relationship between offspring size and yolk sac volume. Journal of Fish Biology, 63: 388-397. 
Johnston, T. A., M. D. Wiegand, W. C. Leggett, R. J. Pronyk, S. D. Dyal, K. E. Watchorn, S. Kollar \& J. M. Casselman. 2007. Hatching success of walleye embryos in relation to maternal and ova characteristics. Ecology of Freshwater Fish, 16: 295-306.

Kjørsvik, E., A. Mangor-Jensen \& I. Holmefjord. 1990. Egg quality in fishes. Advances in Marine Biology, 26: 71-113.

King, H. R., N. W. Pankhurst \& M. Watts. 2007. Reproductive sensitivity to elevated water temperatures in female Atlantic salmon is heightened at certain stages of vitellogenesis. Journal of Fish Biology, 70: 190-205.

Lichtenstein, G., M. Elisio \& L. A. Miranda. 2010. Development of sperm cryopreservation techniques in pejerrey Odontesthes bonariensis. Aquaculture, 306: 357-361.

Lubzens, E., G. Young, J. Bobe \& J. Cerdà. 2010. Oogenesis in teleosts: How fish eggs are formed. General and Comparative Endocrinology, 165: 367-389.

Luchini, L., R. Quirós \& T. Avedaño. 1984. Cultivo del pejerrey (Basilichthys bonariensis) en estanques. Memoria de la Asociación Latinoamericana de Acuicultura, 5: 581-587.

Marteinsdottir, G. \& A. Steinarsson. 1998. Maternal influence on the size and viability of Iceland cod Gadus morhua eggs and larvae. Journal of Fish Biology, 52: 1241-1258.

Miranda, L. A., M. C. Cassará \& G. M. Somoza. 2005. Increase in milt production by hormonal treatment in the pejerrey fish Odontesthes bonariensis (Valenciennes 1835). Aquaculture Research, 36: 1473-1479.

Miranda, L. A., G. E. Berasain, C. A. M. Velasco, Y. G. M. Shirojo \& G. M. Somoza. 2006. Natural spawning and intensive culture of pejerrey Odontesthes bonariensis juveniles. Biocell, 30: 157-162.

Miranda, L. A. \& G. M. Somoza. 2009. Spawning induction of pejerrey Odontesthes bonariensis in captivity using sustainedrelease gonadotropin releasing hormone agonist implants. Aquaculture Research, 41: 129-134.

Miranda, L. A., T. Chalde, M. Elisio \& C. A. Strüssmann. 2013. Effects of global warming on fish reproductive endocrine axis, with special emphasis in pejerrey Odontesthes bonariensis. General and Comparative Endocrinology, 192: 45-54.

Ojanguren, A. F., F. G. Reyes-Gavilhn \& F. Braña. 1996. Effects of egg size on offspring development and fitness in brown trout, Suho trutta L. Aquaculture, 147: 9-20.

Pankhurst, N. W. \& H. R. King. 2010. Temperature and salmonid reproduction: implication for aquaculture. Journal of Fish Biology, 76: 69-85.
Policar, T., P. Podhorec, V. Stejskal, J. Hamackova \& S. M. H. Alavi. 2010. Fertilization and hatching rates and larval performance in captive common barbell (Barbus barbus L.) throughout the spawning season. Journal of Applied Ichthyology, 26: 812-815.

Rosen, D. E. \& L. R. Parenti. 1981. Relationships of Oryzias, and the groups of Atherinomorph fishes. American Museum Novitates, 2719: 1-25.

Ross, L. G., C. A. Martinez Palacios \& E. J. Morales. 2008. Developing native fish species for aquaculture: the interacting demands of biodiversity, sustainable aquaculture and livelihoods. Aquaculture Research, 39: 675-683.

Rouxel, C., M. Suquet, J. Cosson, A. Severe, L. Quemener \& C. Fauvel. 2008. Changes in Atlantic cod (Gadus morhua L.) sperm quality during the spawning season. Aquaculture Research, 39: 434-440.

Somoza, G. M., L. A. Miranda, L. G. Guilgur \& P. H. StroblMazzulla. 2006. Characterization of the brain-pituitary axis in pejerrey Odontesthes bonariensis. Biocell, 30: 89-95.

Somoza, G. M., L. A. Miranda, G. E. Berasain, D. Colautti, M. Remes Lenicov \& C. A. Strüssmann. 2008. Historical aspects, current status and prospects of pejerrey aquaculture in South America. Aquaculture Research, 39: 784-793.

Strüssmann, C. A. 1989. Basic studies on seed production of pejerrey Odontesthes bonariensis. Unpublished Ph.D. Dissertation. Tokyo University of Fisheries, Tokyo, Japan, 351p.

Strüssmann, C. A. \& F. Takashima. 1989. PNR, histology and morphometry of starved pejerrey Odontesthes bonariensis larvae. Nippon Suisan Gakk, 55: 237-246.

Uusi-Heikkilä, S., C. Wolter, T. Meinelt \& R. Arlinghaus. 2010. Size-dependent reproductive success of wild zebrafish Danio rerio in the laboratory. Journal of Fish Biology, 77: 552-569.

Velasco, C. A., G. E. Berasain \& M. Ohashi. 2008. Producción intensiva de juveniles de pejerrey (Odontesthes bonariensis). Biología Acuática, 24: 53-58.

Wiegand, M. D. 1996. Composition, accumulation and utilization of yolk lipids in teleost fish. Reviews in Fish Biology and Fisheries, 6: 259-286.

Submitted August 30, 2013 Accepted January 21, 2014 by Bernardo Baldisserotto Published September 30, 2014 